\title{
Effect of Nitrogen and Spacing Levels on Growth and Yield Parameters of Kasuri methi (Trigonella corniculata L.) var. Pusa Kasuri
}

\author{
G. Anupama*, L.N. Hegde, N.K. Hegde, V. Devappa, \\ A.B. Mastiholi and Sandhyarani Nishani
}

Department of Plantation, Spices, Medicinal and Aromatic plants, Kittur Rani Channamma College of Horticulture, Arabhavi-591 310,University of Horticultural Sciences, Bagalkot- 587 102, Karnataka, India

*Corresponding author

\section{A B S T R A C T}

\section{Keywords}

Kasuri methi (Trigonella corniculata L.) var. Pusa Kasuri, Nitrogen levels, Spacing levels, Growth and yield parameters.

Article Info

Accepted:

19 July 2017

Available Online:

10 September 2017
A field experiment was conducted with 4 nitrogen and 4 spacing levels in factorial randomized block design with three replications. Maximum plant height, number of branches, number of leaves, total dry matter accumulation per plant and fresh and dry yield per plant and per hectare were recorded when the crop was applied with $80 \mathrm{~kg}$ N/ha with a spacing of $30 \times 20 \mathrm{~cm}\left(\mathrm{~N}_{4} \mathrm{~S}_{4}\right)$ under the Northern dry zone of Karnataka.

\section{Introduction}

Kasuri methi (Trigonella corniculata L.) is a semi-arid crop belonging to the family Fabaceae. It is commonly known as Champa methi' and 'marwari methi', is a diffused sub erects and strongly scented annual herb. It remains rosette condition during most of the vegetative growth period (Anon., 2004).

It is originated in Mediterranean region and near east countries. The dried leaves are the economic part of this plant. In India, it is mainly grown in northern states like Maharashtra Rajasthan, Gujarat, Uttarpradesh, Madhya Pradesh, Haryana and Punjab.
Rajasthan occupies 80 per cent area and production of Kasuri methi in the country.

Kasuri methi is a multipurpose crop. Its every part is useful and is utilized in one or other forms as food, fodder, medicine and cosmetics. The fresh green leaves are used as condiment for giving delicious flavor. These have an aromatic odor and agreeable spicy taste. Being odoriferous, the dried seeds and their powder are used as condiment flavoring agent and for medicinal purposes.

Kasuri methi is recognized as a vital source of essential minerals, vitamins and dietary fibers. 
The green leaves contain several alkaloids like trigonelline, choline, gentianine and carpain. It contains moisture (86.1\%), protein $(4.4 \%)$, fat $(0.9 \%)$, fiber $(1.1 \%)$, other carbohydrates (6\%) and ash (1.5\%). In addition, leaves are rich source of vitamins such as carotene $(2.34 \mathrm{mg} / 100 \mathrm{~g}$ of fresh edible portion), thiamine $(0.04 \mathrm{mg})$, riboflavin $(0.31 \mathrm{mg})$, nicotinic acid $(0.8 \mathrm{mg})$ and vitamin $\mathrm{C}(52.0 \mathrm{mg} / 100 \mathrm{~g}$ of edible portion).

Kasuri methi has many uses such as flavoring and medicinal purpose, is gaining importance in recent years and there is a good demand for the dried leaves in the market. The dried leaves are regularly sold in the super markets as popular flavoring material. The scientific information on cultivation and nutrient management of this crop is very less.

\section{Materials and Methods}

A field experiment was conducted at the department of Plantation, Spices, Medicinal and Aromatic Crops, Kittur Rani Channamma College of Horticulture, Arabhavi, University of Horticultural Sciences, Bagalkot from November, 2011 to January, 2012. Geographically, the Arabhavi lies in the Zone-3 of Region-2 in the agro-climatic zone of Karnataka. It is situated at $16^{\mathrm{O}} 15^{\prime}$ North latitude and $74^{\circ} 45^{\circ}$ East longitude and at an altitude of $612 \mathrm{~m}$ above the mean sea level. The soil of the experimental site was medium deep black in texture. The experiment was laid out with 4 levels of nitrogen $\mathrm{N}_{1}-20 \mathrm{~kg}$, $\mathrm{N}_{2^{-}}-40 \mathrm{~kg}, \mathrm{~N}_{3^{-}} 60 \mathrm{~kg}$ and $\mathrm{N}_{4}-80 \mathrm{~kg} \mathrm{~N} / \mathrm{ha}$ and spacing levels viz., $S_{1^{-}} 20 \times 10 \mathrm{~cm}, S_{2^{-}} 20 \mathrm{x}$ $20 \mathrm{~cm}, \mathrm{~S}_{3^{-}}-30 \times 10 \mathrm{~cm}$ and $\mathrm{S}_{4^{-}}-30 \times 20 \mathrm{~cm}$. It was laid out in RBD with factorial concept in three replications.

Healthy seeds of variety Pusa Kasuri were used for sowing. They were sown on $28^{\text {th }}$ November, 2011 as above mentioned spacings. Furrows were properly covered with a thin layer of soil and the plots were irrigated with small stream of water. Farm yard manure was applied one week before the sowing of crop at the rate of 10 tones per hectare as a common dose for all the treatments. The plots were supplied with half the dose of nitrogen (in the form of urea) and full dose of phosphorus (in the form of single super phosphate) as per the treatments.

The remaining half dose of nitrogen was supplemented 30 days after sowing as top dressing and the light earthing up was done. Observations on growth and yield parameters were recorded using five plants per plot and the data collected during the study was subjected to Statistical analysis using the Fischer's method of analysis of variance technique as given by Panse and Sukhatme (1967).

\section{Results and Discussion}

The plant height, number of branches, number of leaves and dry matter production gram per plant responded significantly to nitrogen levels. Maximum plant height of $19.02 \mathrm{~cm}$ number of branches (7.35), number of leaves (71.04) and total dry matter accumulation $(15.96 \mathrm{~g})$ were recorded with the application of $80 \mathrm{~kg} \mathrm{~N}$ per hectare $\left(\mathrm{N}_{4}\right)$ (Table 1). These results are in close proximity with the findings of Naveen (2010) in Kasuri methi, Jamal (2009) in Mentha spicata L, Tuncturk et al., (2011) in fenugreek, Sharma (2000) in fenugreek and Patidar et al., (2004) in cumin.

The increase in plant height, number of branches, number of leaves and dry matter production per plant was observed with an increase in spacing. Maximum plant height $(17.57 \mathrm{~cm})$, number of branches (6.86), number of leaves at 60 DAS (61.59) and dry matter production $(14.03 \mathrm{~g} /$ plant $)$ at $75 \mathrm{DAS}$ were recorded with the crop spaced at $30 \times 20$ $\mathrm{cm}\left(\mathrm{S}_{4}\right)$. The results are in agreement with the 
findings of (Ramachandra et al., 2002) in patchouli, Umesha et al., (1990) in clocimum and Shivajiprasad and Saxena (1980) in pepper mint.

Table.1 Effect of nitrogen and spacing levels on plant height, number of branches, number of leaves and total dry matter at different stages of plant growth of Kasuri methi

(Trigonella corniculata L.) var. Pusa Kasuri

\begin{tabular}{|c|c|c|c|c|}
\hline Treatment & $\begin{array}{c}\text { Plant height } \\
(\mathbf{c m})\end{array}$ & $\begin{array}{c}\begin{array}{c}\text { Number of } \\
\text { branches }\end{array} \\
\end{array}$ & $\begin{array}{c}\text { Number of } \\
\text { leaves }\end{array}$ & $\begin{array}{c}\text { Total dry matter } \\
\text { (g/plant) }\end{array}$ \\
\hline \multicolumn{5}{|l|}{ Nitrogen level (N) } \\
\hline$N_{1}: 20 \mathrm{~kg} / \mathrm{ha}$ & 16.16 & 6.54 & 52.64 & 10.33 \\
\hline $\mathrm{N}_{2}: 40 \mathrm{~kg} / \mathrm{ha}$ & 17.15 & 6.61 & 56.15 & 12.75 \\
\hline$N_{3}: 60 \mathrm{~kg} / \mathrm{ha}$ & 17.32 & 6.76 & 64.39 & 13.71 \\
\hline$N_{4}: 80 \mathrm{~kg} / \mathrm{ha}$ & 19.02 & 7.35 & 71.04 & 15.96 \\
\hline Mean $(\mathbf{N})$ & 17.41 & 6.81 & 61.05 & 13.19 \\
\hline S.Em \pm & 0.18 & 0.03 & 0.45 & 0.08 \\
\hline CD@ $5 \%$ & 0.51 & 0.1 & 1.29 & 0.23 \\
\hline \multicolumn{5}{|l|}{ Spacing level (S) } \\
\hline$S_{1}: 20 \times 10 \mathrm{~cm}(50,000$ plants/ha $)$ & 17.29 & 6.78 & 60.56 & 12.4 \\
\hline$S_{2}: 20 \times 20 \mathrm{~cm}(25,000$ plants/ha $)$ & 17.37 & 6.8 & 60.8 & 12.95 \\
\hline$S_{3}: 30 \times 10 \mathrm{~cm}(3,33000$ plants $/ \mathrm{ha})$ & 17.43 & 6.83 & 61.27 & 13.37 \\
\hline$S_{4}: 30 \times 20 \mathrm{~cm}(1,66000$ plants $/ \mathrm{ha})$ & 17.57 & 6.86 & 61.59 & 14.03 \\
\hline Mean (S) & 17.41 & 6.78 & 61.05 & 13.19 \\
\hline S. Em \pm & 0.18 & 0.03 & 0.45 & 0.08 \\
\hline CD@ $9 \%$ & NS & NS & NS & 0.23 \\
\hline \multicolumn{5}{|l|}{ Interaction ( $\mathrm{N} \times \mathrm{S})$} \\
\hline $\mathbf{N}_{1} \mathbf{S}_{\mathbf{1}}$ & 16.08 & 6.49 & 52.03 & 9.49 \\
\hline $\mathbf{N}_{1} \mathbf{S}_{2}$ & 16.17 & 6.53 & 52.49 & 9.97 \\
\hline $\mathbf{N}_{1} \mathbf{S}_{3}$ & 16.18 & 6.55 & 52.74 & 10.54 \\
\hline $\mathbf{N}_{1} \mathbf{S}_{4}$ & 16.22 & 6.61 & 53.29 & 10.97 \\
\hline $\mathbf{N}_{2} \mathbf{S}_{1}$ & 17.1 & 6.56 & 55.66 & 11.3 \\
\hline $\mathbf{N}_{2} \mathbf{S}_{2}$ & 17.14 & 6.59 & 55.74 & 11.58 \\
\hline $\mathbf{N}_{2} \mathbf{S}_{3}$ & 17.17 & 6.63 & 56.29 & 12.59 \\
\hline $\mathbf{N}_{2} \mathbf{S}_{4}$ & 17.19 & 6.66 & 56.89 & 13 \\
\hline $\mathbf{N}_{3} \mathbf{S}_{1}$ & 17.21 & 6.73 & 63.65 & 13.83 \\
\hline $\mathbf{N}_{3} \mathbf{S}_{2}$ & 17.33 & 6.74 & 64.01 & 13.22 \\
\hline $\mathbf{N}_{3} \mathbf{S}_{3}$ & 17.33 & 6.77 & 64.89 & 13.58 \\
\hline $\mathbf{N}_{3} \mathbf{S}_{4}$ & 17.42 & 6.79 & 64.98 & 13.71 \\
\hline $\mathbf{N}_{4} \mathbf{S}_{1}$ & 18.76 & 7.33 & 70.89 & 14.32 \\
\hline $\mathbf{N}_{4} \mathbf{S}_{2}$ & 18.83 & 7.34 & 70.96 & 15.3 \\
\hline $\mathbf{N}_{4} \mathbf{S}_{3}$ & 19.04 & 7.36 & 71.14 & 15.64 \\
\hline $\mathbf{N}_{4} \mathbf{S}_{4}$ & 19.45 & 7.37 & 71.18 & 16.23 \\
\hline Mean $(N \times S)$ & 17.41 & 6.81 & 61.05 & 16.68 \\
\hline S.Em \pm & 0.35 & 0.07 & 10.89 & 0.16 \\
\hline CD at $5 \%$ & 1.02 & 0.19 & 2.58 & 0.47 \\
\hline
\end{tabular}

$*$ DAS- Days after sowing, NS: Non significant 
Table.2 Effect of nitrogen and spacing levels on Fresh and dry yield of Kasuri methi (Trigonella corniculata L.) var. Pusa Kasuri

\begin{tabular}{|c|c|c|c|c|}
\hline Treatment & $\begin{array}{c}\text { Fresh } \\
\text { yield } \\
\text { (g/plant) }\end{array}$ & $\begin{array}{c}\text { Fresh yield } \\
\text { (t/ha) }\end{array}$ & $\begin{array}{c}\text { Dry yield } \\
\text { (g/plant) }\end{array}$ & $\begin{array}{c}\text { Dry yield } \\
\text { (t/ha) }\end{array}$ \\
\hline \multicolumn{5}{|l|}{ Nitrogen level (N) } \\
\hline $\mathrm{N}_{1}: 20 \mathrm{~kg} / \mathrm{ha}$ & 55.23 & 17.15 & 11.00 & 3.42 \\
\hline $\mathrm{N}_{2}: 40 \mathrm{~kg} / \mathrm{ha}$ & 57.87 & 17.99 & 11.58 & 3.59 \\
\hline$N_{3}: 60 \mathrm{~kg} / \mathrm{ha}$ & 59.61 & 18.59 & 12.10 & 3.77 \\
\hline$N_{4}: 80 \mathrm{~kg} / \mathrm{ha}$ & 63.36 & 19.61 & 12.55 & 3.90 \\
\hline Mean $(\mathbf{N})$ & 59.02 & 18.33 & 11.81 & 3.67 \\
\hline S.Em \pm & 0.42 & 0.13 & 0.03 & 0.01 \\
\hline CD@ $5 \%$ & 1.22 & 0.39 & 0.08 & 0.03 \\
\hline \multicolumn{5}{|l|}{ Spacing level (S) } \\
\hline$S_{1}: 20 \times 10 \mathrm{~cm}(50,000$ plants/ha $)$ & 57.77 & 28.88 & 11.60 & 5.80 \\
\hline$S_{2}: 20 \times 20 \mathrm{~cm}(25,000$ plants/ha $)$ & 58.4 & 14.6 & 11.72 & 2.93 \\
\hline$S_{3}: 30 \times 10 \mathrm{~cm}(3,33000$ plants $/ \mathrm{ha})$ & 59.54 & 19.83 & 11.87 & 3.95 \\
\hline $\mathrm{S}_{4}: 30 \times 20 \mathrm{~cm}(1,66000$ plants $/ \mathrm{ha})$ & 60.36 & 10.02 & 12.04 & 2.00 \\
\hline Mean (S) & 59.02 & 18.33 & 11.81 & 3.67 \\
\hline S.Em \pm & 0.42 & 0.13 & 0.03 & 0.01 \\
\hline CD@ $5 \%$ & 1.22 & 0.39 & 0.08 & 0.03 \\
\hline \multicolumn{5}{|l|}{ Interaction $(\mathbf{N} \times \mathbf{S})$} \\
\hline $\mathbf{N}_{1} \mathbf{S}_{1}$ & 54.02 & 27.01 & 10.74 & 5.37 \\
\hline $\mathbf{N}_{1} \mathbf{S}_{2}$ & 54.55 & 13.64 & 10.90 & 2.73 \\
\hline $\mathbf{N}_{1} \mathbf{S}_{3}$ & 55.7 & 18.55 & 11.11 & 3.70 \\
\hline $\mathbf{N}_{1} \mathbf{S}_{4}$ & 56.63 & 9.4 & 11.25 & 1.87 \\
\hline $\mathbf{N}_{2} \mathbf{S}_{1}$ & 56.63 & 28.32 & 11.29 & 5.65 \\
\hline $\mathbf{N}_{2} \mathbf{S}_{2}$ & 57.48 & 14.37 & 11.46 & 2.86 \\
\hline $\mathbf{N}_{2} \mathbf{S}_{3}$ & 58.57 & 19.5 & 11.67 & 3.89 \\
\hline $\mathbf{N}_{2} \mathbf{S}_{4}$ & 58.8 & 9.76 & 11.88 & 1.97 \\
\hline $\mathbf{N}_{3} \mathbf{S}_{1}$ & 59.22 & 29.61 & 11.97 & 5.99 \\
\hline $\mathbf{N}_{3} \mathbf{S}_{2}$ & 59.59 & 14.9 & 12.07 & 3.02 \\
\hline $\mathbf{N}_{3} \mathbf{S}_{3}$ & 59.73 & 19.89 & 12.13 & 4.04 \\
\hline $\mathbf{N}_{3} \mathbf{S}_{4}$ & 59.9 & 9.94 & 12.24 & 2.03 \\
\hline $\mathbf{N}_{4} \mathbf{S}_{1}$ & 61.2 & 30.6 & 12.38 & 6.19 \\
\hline $\mathbf{N}_{4} \mathbf{S}_{2}$ & 61.98 & 15.5 & 12.47 & 3.12 \\
\hline $\mathbf{N}_{4} \mathbf{S}_{3}$ & 64.16 & 21.37 & 12.56 & 4.18 \\
\hline $\mathbf{N}_{4} \mathbf{S}_{4}$ & 66.1 & 10.97 & 12.80 & 2.13 \\
\hline Mean (N x S) & 59.02 & 18.33 & 11.81 & 3.67 \\
\hline S.Em \pm & 0.84 & 0.27 & 0.06 & 0.02 \\
\hline CD at $5 \%$ & 2.44 & 0.77 & 0.16 & 0.06 \\
\hline
\end{tabular}


The interaction effect of nitrogen and spacing levels was found significant with respect to plant height, number of branches, number of leaves and total dry matter accumulation per plant. The treatment combination of $80 \mathrm{~kg} \mathrm{~N}$ per hectare with $30 \times 20 \mathrm{~cm}\left(\mathrm{~N}_{4} \mathrm{~S}_{4}\right)$ recorded maximum plant height $(19.45 \mathrm{~cm})$, number of branches (7.37), number of leaves (71.18) and total dry matter accumulation per plant (16.23 g). This could be attributed to the enhanced availability of fertilizers at the appropriate time along with congenial climatic conditions, which might have resulted in increased photosynthetic rate and accumulation of metabolites in plants (Table 1).

Application of $80 \mathrm{~kg} \mathrm{~N}$ per hectare $\left(\mathrm{N}_{4}\right)$ resulted in production of maximum fresh and dry yield per plant and per hectare (Table 2). The increase in yield might be attributed to the fact that under increasing nitrogen levels, there would be luxuriant growth of the plant which is evident from vegetative growth, which led to the production of more fresh and dry herbage yield.

The fresh and dry herb yield per plant, maximum value was recorded in wider spacing of $30 \times 20 \mathrm{~cm} \quad\left(\mathrm{~S}_{4}\right)$ (Table 2). Whereas, the minimum yield was noticed in closer spacing of $20 \times 10 \mathrm{~cm}\left(\mathrm{~S}_{1}\right)$. The higher yield might be due to more number of branches, leaves, and dry matter per unit area. The different spacing levels showed significant variation on fresh and dry yield of herb per hectare. The closer spacing of $20 \times 10$ $\mathrm{cm}\left(\mathrm{S}_{1}\right)$ produced significantly higher fresh and dry herb yield per hectare, while the minimum yield per hectare was recorded in $30 \times 20 \mathrm{~cm}\left(\mathrm{~S}_{4}\right)$. The higher yield might be due to more number of plants per unit area. Similar results were observed earlier by Pal et al., (1987) Ocimum viride, Prakasarao et al., (1983) in davana, Farooqi et al., (1990) in davana and Harshavardhan et al., (2005) Mellissa officinalis L.
The interaction effect between nitrogen and spacing levels differed significantly with respect to fresh and dry herb yield. The fresh and dry yield per plant was recorded maximum $(66.10 \mathrm{~g}$ and $12.80 \mathrm{~g})$ in $\mathrm{N}_{4} \mathrm{~S}_{4}$ and the minimum (54.02 $\mathrm{g}$ and $10.74 \mathrm{~g}$ ) was observed in $\mathrm{N}_{1} \mathrm{~S}_{1}$ (Table 2). This might be due to combined effect of treatments and active growth period which contributed to maximum fresh and dry yield per plant. Interaction effect was significantly differed in fresh and dry yield per hectare. The higher nitrogen dose with closer spacing that is $80 \mathrm{~kg} \mathrm{~N}$ per hectare with $20 \times 10 \mathrm{~cm}$ spacing $\left(\mathrm{N}_{4} \mathrm{~S}_{1}\right)$ recorded maximum fresh and dry herb yield per hectare and the least was observed in $\mathrm{N}_{1} \mathrm{~S}_{4}$. This might be due to application of higher nitrogen and more population per unit area which helped in accumulation of more biomass and dry matter in the plants. The results are conformity with the results of Gupta and Shahi (1999) in Ocimum canum, Randhawa et al., (1996) in dill and Yadav et al., (1983) in Japanese mint.

From the present investigation, it can be concluded that the Kasuri methi is beneficial for obtaining the maximum growth and higher yields, under the northern dry zone of Karnataka.

\section{References}

Anonymous, 2004, Trigonella corniculata Linn., Wealth of India, Raw materials, CSIR, New Delhi, 5: 252-258.

Farooqi, A.A., Devaiaha, K. A., Vasundhara, M., Daharatha Rao, N. D. and Rao, 1990, Influence of plant density on growth and yield in davana. Indian Perfumer, 34 (4): 274-277.

Pal, S., Balyan, S. S., Singh, S. N. and Singh, A., 1987, Influence of plant spacing on herbage yield in Ocimum viride Wild. Indian Perfumer, 31 (2): 86-88.

Panse, V.G., and Sukhatme, P.V., 1967, 
Stastical Methods for Agricultural Workers, Indian council of Agricultural Research, New Delhi.

Patidar, M., Balaram, B., Singh, M. P. and Singh, G., 2004, Influence of nitrogen on growth and yield of Cumin (Cuminum cyminum L.). J. Spices and Arom. Crops, 13 (2): 126-128.

Prakash Rao, E.V.S., Singh, M., And Ganesh Rao, R. S., 1983, Effect of nitrogen and plant spacing on the growth, yield and nutrient uptake in davana (Artimisia pallens Wall.). Int. J. of Tropical Agric., 1(3): 187-192.

Ramachandra, K. M., Vasundhara, M., Farooqi, A. A. and Srinivasappa, K. N., 2002, Evaluation of Patchouli (Pogostemon cablin Benth.) varieties in relation to different plant densities. Indian Perfumer, 46: 7-14.

Randhawa, G. S., Saini, S. S., Singh, J. and Cracker, L. E., 1996, Effect of plant spacings and nitrogen levels on the seed yield of dill seed (Anethum graveolens L.). Acta Hort., 426: 623-
628.

Sharma, S. K., 2000, Response of nitrogen and spacing on fenugreek seed production. Horticultural Journal, 13 (2): 39-42.

Shivajiprasad and Saxena, M. C., 1980, Effect of row spacing on the growth and development of pepper mint in Tarai. Ind. J. Pl. Physiol., 23: 119-126.

Tuncturk, R., Celen, A and Tuncturk, M., 2011, Effect of Nitrogen and spacing levels on growth and yield attributes of fenugreek (Trigonella fonenumgrecaum L.). Turk. J. field crops, 16 (1): 69-75.

Umesha, K., Bojappa, K. M., Farooqi, A. A. and Suresh, N. S., 1990, Influence of plant density on growth and yield of Clocimum (Ocimum gratissium L.). Indian Perfumer, 34 (3): 173-175.

Yadav, R. L., Mohan, R. and Ram, M., 1983, Yield and quality of essential oil of Japanese mint as affected by $\mathrm{N}$ rates and row spacing's. Madras Agri. J., 70(7): 454-457.

\section{How to cite this article:}

Anupama, G., L.N. Hegde, N.K. Hegde, V. Devappa, A.B. Mastiholi and Sandhyarani Nishani. 2017. Effect of Nitrogen and Spacing Levels on Growth and Yield Parameters of Kasuri methi (Trigonella corniculata L.) var. Pusa Kasuri. Int.J.Curr.Microbiol.App.Sci. 6(9): 1464-1469. doi: https://doi.org/10.20546/ijcmas.2017.609.178 